Journal of Animal and Veterinary Advances 11 (5): 681-686, 2012

ISSN: $1680-5593$

(C) Medwell Journals, 2012

\title{
Catch per Unit Effort and Mortality Rates of Two Sparid Species, Pagellus acarne and Pagellus erythrinus from Bottom Trawl Fishery in Izmir Bay, Aegean Sea
}

\author{
${ }^{1}$ Rasit Gurbet, ${ }^{1}$ Okan Akyol and ${ }^{2}$ Esin Yalcin \\ ${ }^{1}$ Faculty of Fisheries, Ege University, 35100 Bornova, Izmir, Turkey \\ ${ }^{2}$ Institute of Marine Science and Technology, Middle East Technical University, \\ Erdemli, Icel, Turkey
}

\begin{abstract}
This study was carried out by using experimental trawl surveys in Izmir bay (Aegean sea) with seasonal basis between 2007 and 2009. A total of 707 specimens of $P$. acarne sampled were ranged from $7 \mathrm{~cm}$ ( $7.5 \mathrm{~g})$ to $19.8 \mathrm{~cm}(137.5 \mathrm{~g})$ with average $12.4 \pm 0.06 \mathrm{~cm} \mathrm{FL}(35.2 \pm 0.57 \mathrm{~g})$ while a total of 1127 P. erythrinus specimens were also ranged from $4.6 \mathrm{~cm}(1.8 \mathrm{~g})$ to $22.3 \mathrm{~cm}(247.8 \mathrm{~g})$ with average $13.1 \pm 0.09 \mathrm{~cm} \mathrm{FL}(50.8 \pm 1.02 \mathrm{~g})$. The maximal CPUE was found in Autumn $\left(0.53 \pm 0.14 \mathrm{~kg} \mathrm{~h}^{-1}\right)$ for $P$. acarne while in Spring $\left(1.29 \pm 0.47 \mathrm{~kg} \mathrm{~h}^{-1}\right)$ for $P$. erythrinus. The high exploitation rates $\left(\mathrm{E}=0.65 \mathrm{year}^{-1}\right.$ for $P$. acarne and $\mathrm{E}=0.61$ year $^{-1}$ for $P$. erythrinus $)$ indicates the over-fishing on both Pagellus populations in the Aegean sea.
\end{abstract}

Key words: Pagellus acarne, Pagellus erythrinus, CPUE, exploitation, mortality, Izmir bay, Aegean sea

\section{INTRODUCTION}

Axillary sea bream, Pagellus acarne (Risso, 1826) and common pandora, Pagellus erythrinus (Linnaeus, 1758) are two widely distributed Sparidae species whose distribution area encompasses both hemispheres from Scandinavia to Senegal and Angola. Both demersal schooling species are preferably inhabit the continental shelf-sandy or muddy-bottoms at depth of $40-200 \mathrm{~m}$ (Spedicato et al., 2002; Golani et al., 2006). These species are generally recognized as being hermaphroditic, protandrous ( $P$. acarne) and protogynous ( $P$. erythrinus) and spawning occurs in the Autumn for P. acarne in the eastern part of the Mediterranean and from Spring to Autumn for $P$. erythrinus (Hureau and Bauchot, 1986).

These species are commercially important and they are fished with a variety of fishing gears such as trawl, gillnet, longline and beach seine. The last Turkish official statistics (Tuik, 2010) shown that total capture production, all of breams was about 1000 tons of which 479 tons (48\%) obtained from the Aegean sea. According to Turkish Fisheries Regulations Circular (TFRC), there is a general $15 \mathrm{~cm}$ Minimum Landing Size (MLS) limitation for the breams (Anonymous, 2008). Officially, there are no specific catch amount records and MLS for neither axillary sea bream nor common pandora. However, recent studies (Kinacigil et al., 2008; Metin et al., 2011) reported that the length at first maturity of $P$. acarne and $P$. erythrinus in the Aegean sea were 14.5 and $15.1 \mathrm{~cm} \mathrm{TL}$, respectively.
Thus, the MLS with $15 \mathrm{~cm}$ in TFRC seems to be reasonable for both species. Studies on the populations of $P$. acarne and $P$. erythrinus species in Turkish seas are relatively scarce and therefore, various aspects of its biology (Tosunoglu et al., 1997; Akyol and Ozekinci, 2000; Metin et al., 2011), by-catch ratios (Akyol, 2003; Ozbilgin et al., 2006) and selectivity (Tosunoglu et al., 2003; Tosunoglu, 2007; Karakulak and Erk, 2008; Ates et al., 2010; Aydin et al., 2011) have been documented. The study of Akyol and Ozekinci (2000) given the mortality rates of $P$. acarne and $P$. erythrinus from beach-seining in the Aegean coasts however, Catch Per Unit Effort (CPUE) were not studied up to now in Turkish seas.

The aim of this study was to determine the stock abundance in relation to CPUE from trawling and mortality rates of $P$. acarne and $P$. erythrinus populations in Izmir bay (Aegean sea).

\section{MATERIALS AND METHODS}

This study was carried out in both free and closed areas for trawlers of Izmir bay (Fig. 1). Sampling was performed seasonal basis between 2007 and 2009 using experimental trawl surveys with $\mathrm{R} / \mathrm{V}$ Egesuf $(27 \mathrm{~m}$ in overall length, $550 \mathrm{hp}$ in engine). Depth of trawl hauls were between 30 and $70 \mathrm{~m}$. Trawl net had a cod-end mesh size of $44 \mathrm{~mm}$ from knot to knot. Speed and duration

Corresponding Author: Rasit Gurbet, Faculty of Fisheries, Ege University, 35100 Bornova, Izmir, Turkey 


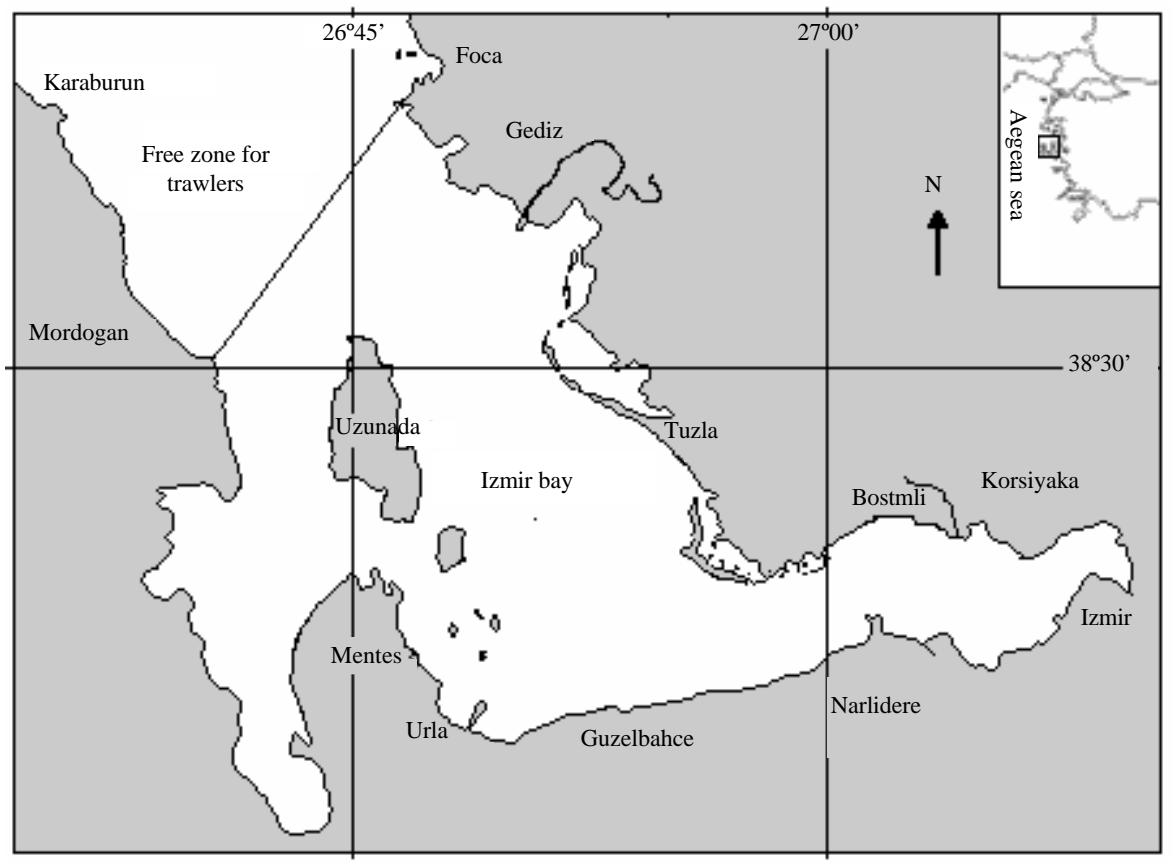

Fig. 1: Sampling area

of trawl operations were kept constant at 2.5 knot and $30 \mathrm{~min}$, respectively. P. acarne was obtained from 56 hauls, 15 in Autumn; 16 in Winter; 13 in Spring and 12 in Summer while $P$. erythrinus was also collected from 69 hauls, 24 in Autumn, 15 in Winter, 17 in Spring and 13 in Summer.

The samples of $P$. acarne $(\mathrm{n}=707)$ and $P$. erythrinus $(\mathrm{n}=1127)$ were examined in the laboratory. Their size (FL in $\mathrm{cm}$ ) and weight (g) were measured and weighed to the nearest $\pm 0.1 \mathrm{~cm}$ and $\pm 0.1 \mathrm{~g}$, respectively. Ageing were made from sagittal otoliths in order to calculating the von Bertalanffy growth parameters (i.e., $\mathrm{L}_{\infty}, \mathrm{K}$ ). The Catch Per Unit Effort (CPUE) was calculated according to Petrakis (1998) as $\mathrm{kg} \mathrm{h}^{-1}$ (i.e., $\mathrm{kg} \mathrm{h}^{-1}$ ) of fishing: the total weight of the species was standardized to $1 \mathrm{~h}$ of towing:

Where:

$$
\mathrm{W}_{\mathrm{i}}=\mathrm{W}_{\mathrm{i}} \times 60 / \mathrm{t}
$$

$\mathrm{W}_{\mathrm{i}}=$ Standardized weight

$\mathrm{w}_{\mathrm{i}}=$ Actual weight

$\mathrm{t}=$ Duration of the tow

The CPUE was estimated as the mean of the standardized weight in the season. $\mathrm{CPUE}=\mathrm{OW}_{\mathrm{i}} \mathrm{N}$ where $\mathrm{N}$ is number of hauls in the season. Natural Mortality $(\mathrm{M})$ of $P$. acarne and $P$. erythrinus were computed from Pauly (1980)'s following multiple regressions equation:

$$
\begin{aligned}
\log _{10} \mathrm{M}= & -0.0066-0.279 \times \log _{10} \mathrm{~L}_{\infty}+0.6543 \times \log _{10} \mathrm{~K}+ \\
& 0.4634 \times \log _{10} \mathrm{~T}
\end{aligned}
$$

Where:

$\mathrm{M}=$ Natural mortality in a given stock

$\mathrm{L}_{\infty}=$ Asymptotic length

$\mathrm{K}=$ Growth coefficient

$\mathrm{T}=$ The annual mean temperature $\left(\right.$ in $\left.{ }^{\circ} \mathrm{C}\right)$ of the sea water

Mean annual sea water temperature for Izmir bay was determined as $18.2^{\circ} \mathrm{C}$ during the sampling period. Total mortality $(Z)$ was estimated from the mean size in the catch, developed by Beverton and Holt (1957). Z can be estimated from mean length in the catch from a given population by means of:

Where:

$$
\mathrm{Z}=\mathrm{K} \times\left(\mathrm{L}_{\infty}-\mathrm{L}_{\text {mean }}\right) /\left(\mathrm{L}_{\text {mean }}-\mathrm{L}^{\prime}\right)
$$

$\mathrm{L}_{\infty}$ and $\mathrm{K}=$ Parameters of the von Bertalanffy growth equations

$\mathrm{L}_{\text {mean }}=$ The mean length in the catch

L' $\quad=$ Some length for which all fish of that length and longer are under full exploitation

$\mathrm{L}^{\prime}$ is the lower limit of the corresponding length interval (Sparre and Venema, 1992). Fishing mortality (F) can be estimated from $\mathrm{F}=\mathrm{Z}-\mathrm{M}$. Once values of $\mathrm{F}$ and $\mathrm{M}$ are available, an Exploitation ratio (E) can be computed from $\mathrm{E}=\mathrm{F} / \mathrm{Z}$. Which allows one to assess if a stock is over fished or not on the assumption that the optimal value of $\mathrm{E}\left(\mathrm{E}_{\mathrm{opp}}\right)$ is about equal to 0.5 (Pauly, 1980). 
All of the means were given with Standard Error $( \pm \mathrm{SE})$. Comparisons of differences among means of CPUEs biomass of both species were tested by Student t-test. In addition, CPUE biomass ratios and the differences among seasons were tested by Kruskal-Wallis test $(\alpha=0.05)$.

\section{RESULTS AND DISCUSSION}

A total of 707 specimens of $P$. acarne sampled were ranged from $7 \mathrm{~cm}(7.5 \mathrm{~g})$ to $19.8 \mathrm{~cm}(137.5 \mathrm{~g})$ with average $12.4 \pm 0.06 \mathrm{~cm} \mathrm{FL}(35.2 \pm 0.57 \mathrm{~g})$ while a total of 1127 $P$. erythrinus specimens were also ranged from $4.6 \mathrm{~cm}$ $(1.8 \mathrm{~g})$ to $22.3 \mathrm{~cm}(247.8 \mathrm{~g})$ with average $13.1 \pm 0.09 \mathrm{~cm}$ FL $(50.8 \pm 1.02 \mathrm{~g})$. The main group of fish was concentrated between 10 and $13 \mathrm{~cm}$ for $P$. acarne and between 10 and $15 \mathrm{~cm}$ for $P$. erythrinus (Fig. 2). Seasonally, the mean CPUEs $\left(\mathrm{kg} \mathrm{h}^{-1}\right)$ for $P$. acarne and P. erythrinus were shown in Table 1 and Fig. 3. The maximal CPUE was found in autumn for $P$. acarne while in spring for $P$. erythrinus. There were no significant differences among the means of

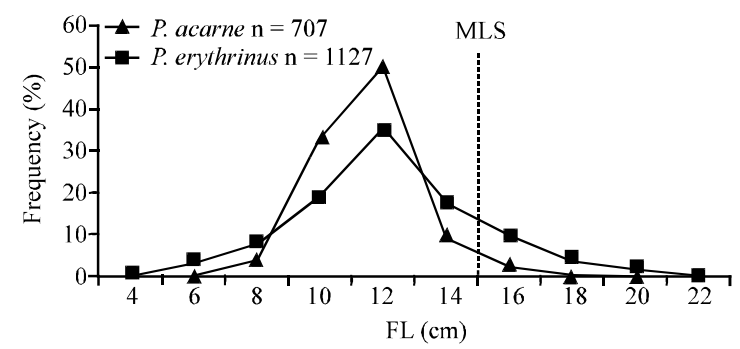

Fig. 2: Length frequency distributions of $P$. acarne and $P$. erythrinus in Izmir bay

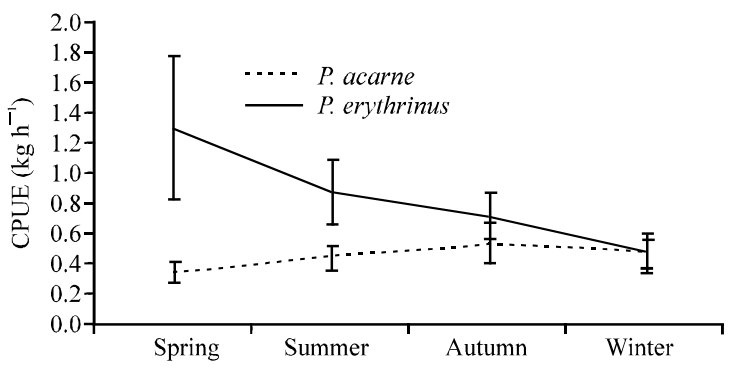

Fig. 3: The seasonal average CPUE fluctuations of $P$. acarne and $P$. erythrinus in Izmir bay (vertical bars indicate $\pm \mathrm{SE}$ )
CPUEs by biomass for both $P$. acarne and $P$. erythrinus ( $>>0.05$ ). Additionally, differences between CPUE biomass ratios and the seasons were not statistically significant for both species ( $\mathrm{p}>0.05$ ).

Mortalities of two Pagellus species from Aegean sea were shown in Table 2. In equations, $\mathrm{L}_{\infty} \mathrm{K}, \mathrm{L}_{\text {mean }}$ and $\mathrm{L}$ ' were assumed as $22.23 \mathrm{~cm}, 0.276$ year $^{-1}, 12.4$ and $11 \mathrm{~cm}$ for $P$. acarne; $28.37 \mathrm{~cm}, 0.151$ year $^{-1}, 13.1 \mathrm{~cm}$ and $11 \mathrm{~cm}$ for $P$. erythrinus, respectively.

The breams are not fully targeted by trawlers in the Aegean sea however, many of these species are caught as by-catch and in general, they are evaluated commercially. In the Aegean sea, more than a hundred trawlers are fished from August to mid April. In addition, a large part of Izmir bay has been closed to the trawlers as well as beach-/purse-seiners since, 2000 in order to protection of this sensitive habitat which covers Posidonia grass. Thus, the bay has been gained a special nursery area for many of marine fish species since then in this study, very small size $(4.6$ and $7 \mathrm{~cm}$ ) of two Pagellus species caught is evident to this situation.

The MLS for breams in Turkish waters is $15 \mathrm{~cm}$ (Anonymous, 2008). The majorities of the fish ranged from $10-13 \mathrm{~cm}$ for $P$. acarne and from $10-15 \mathrm{~cm}$ for $P$. erythrinus and 97 and $84 \%$ of populations were smaller than MLS, respectively. Tosunoglu et al. (1997) reported that the fork lengths of $P$. acarne and $P$. erythrinus in Izmir bay were between 9.8 and $14.8 \mathrm{~cm}$ and between 7 and $24.5 \mathrm{~cm}$, respectively. Tosunoglu (2007) also given that the $\mathrm{FL}$ of $P$. acarne and $P$. erythrinus in Izmir bay were ranged from $8.4-15 \mathrm{~cm}$ and from $7.4-23 \mathrm{~cm}$, respectively. Recently, Metin et al. (2011) determined that the total length of P. erythrinus was ranged from $4.1-27.8 \mathrm{~cm}$ in Izmir bay. All of the length ranges of two species from trawl samplings in Izmir bay were the similar.

Whereas Moutopoulos and Stergiou (2002) obtained seasonally both fish species with gillnets and longlines during 1997-98 from Cyclades (off Naxos Island, Greece) in the Aegean sea that the total length intervals were between 15.3 and $62.6 \mathrm{~cm}$ for $P$. acarne and between 13.1 and $37.6 \mathrm{~cm}$ for $P$. erythrinus. It seems that gillnet and longline are the most size selective than the trawl.

Table 1: The seasonal average CPUE values and total landings of $P$. acarne and $P$. ervthrinus from bottom trawl surveys in Izmir bay

\begin{tabular}{|c|c|c|c|c|c|c|c|c|}
\hline \multirow[b]{2}{*}{ Seasons } & \multicolumn{4}{|c|}{ Pagellus acarne } & \multicolumn{4}{|c|}{ Pagellus erythrinus } \\
\hline & No. of hauls & $\mathrm{n}$ & Landings $(\mathrm{kg})$ & CPUE $\left(\mathrm{kg} \mathrm{h}^{-1}\right)$ & No. of hauls & $\mathrm{n}$ & Landings $(\mathrm{kg})$ & CPUE $\left(\mathrm{kg} \mathrm{h}^{-1}\right)$ \\
\hline Winter & 16 & 200 & 7.30 & $0.46 \pm 0.10$ & 15 & 173 & 6.89 & $0.46 \pm 0.13$ \\
\hline Spring & 13 & 94 & 4.35 & $0.33 \pm 0.07$ & 17 & 380 & 21.90 & $1.29 \pm 0.47$ \\
\hline Summer & 12 & 205 & 5.15 & $0.43 \pm 0.09$ & 13 & 220 & 11.29 & $0.87 \pm 0.21$ \\
\hline Autumn & 15 & 208 & 7.97 & $0.53 \pm 0.14$ & 24 & 354 & 17.12 & $0.71 \pm 0.15$ \\
\hline Total & 56 & 707 & 24.77 & $0.44 \pm 0.05$ & 69 & 1127 & 57.20 & $0.83 \pm 0.14$ \\
\hline
\end{tabular}


Table 2: Mortalities (M, F, Z) and Exploitation rate (E) of P. acarne and P. erythrimus in Izmir bay

\begin{tabular}{|c|c|c|c|c|}
\hline Species & $\begin{array}{c}\text { Natural } \\
\text { mortality } \\
\left(\text { Myear }^{-1}\right)\end{array}$ & $\begin{array}{l}\text { Fishing } \\
\text { mortality } \\
\left(\text { F year }^{-1}\right)\end{array}$ & $\begin{array}{c}\text { Total } \\
\text { mortality } \\
\left(\text { Z year }^{-1}\right)\end{array}$ & $\begin{array}{l}\text { Exploitation } \\
\text { rate }\left(\text { E year }^{-1}\right)\end{array}$ \\
\hline P. acarne & 0.68 & 1.26 & 1.94 & 0.65 \\
\hline P. erythrinus & 0.43 & 0.67 & 1.10 & 0.61 \\
\hline
\end{tabular}

Santos et al. (1995) proved that the gillnet selectivity for both species in Algarve coast (South Portugal) were 15-25, 18-27and 20-29 cm for $P$. acarne and 15-25, 16-27 and $19-30 \mathrm{~cm}$ for $P$. erythrinus, respectively by the 60,70 and $80 \mathrm{~mm}$ mesh sizes. In the Northern Aegean sea, Karakulak and Erk (2008) also determined that the selectivity of gillnet nets with 40 and $44 \mathrm{~mm}$ mesh for $P$. acarne were 15.23 and $16.76 \mathrm{~cm}$, respectively.

Ozbilgin et al. (2006) computed that the ratio of by-catch from trawl fishery in Izmir bay in terms of MLS was $99 \%$ for $P$. acarne and $95 \%$ for $P$. erythrinus. Akyol (2003) also reported that the illegal landing percentage of $P$. erythrinus from beach-seining in the Aegean coasts was $75 \%$ concerning with MLS.

In Izmir bay, Tosunoglu (2007) calculated that the retention lengths $\left(\mathrm{L}_{50}\right)$ of $P$. acarne and $P$. erythrinus in bottom trawl nets ( $44 \mathrm{~mm}$ diamond mesh) were 13.6 and $12.4 \mathrm{~cm}$, respectively. This result shows that the legal mesh size $(44 \mathrm{~mm})$ of Turkish bottom trawl nets is still unselective for both species. Whereas the better selection for both fish have achieved with enlarged mesh size by Aydin et al. (2011). The researchers proved that the $50 \mathrm{~mm}$ diamond mesh cod-end for $P$. acarne $\left(\mathrm{L}_{50}=\right.$ $15.3 \mathrm{~cm})$ and for $P$. erythrinus $\left(\mathrm{L}_{50}=15 \mathrm{~cm}\right)$ is more selective than $44 \mathrm{~mm}$.

In fishBase, maximum-common lengths of $P$. acarne and $P$. erythrinus are $36-25$ and $60-25 \mathrm{~cm}$ SL, respectively (Froese and Pauly, 2011). Thus, two Pagellus species' populations in Izmir bay were not even reach to the common length.

In general, CPUE is used as an index of abundance meaning that a proportional change in CPUE is expected to represent the same proportional change in stock size (FAO, 1999). In this study, the highest mean CPUEs from trawl surveys were determined as $0.53 \pm 0.14 \mathrm{~kg} \mathrm{~h}^{-1}$ in Autumn for P. acarne and $1.29 \pm 0.47 \mathrm{~kg} \mathrm{~h}^{-1}$ in Spring for $P$. erythrinus. In fact, when the CPUE of $P$. acarne was increasing, CPUE of $P$. erythrinus was decreased. On the other hand, there was a seasonally cross-correlation regarding fish abundance between $P$. acarne and $P$. erythrinus. In total, abundance of $P$. erythrinus in terms of landings and CPUE was about two-fold of $P$. acarne. Hureau and Bauchot (1986) stated that in Winter, $P$. erythrinus population moves to the deeper waters depending on the cold water conditions. Thus, this behavior of $P$. erythrinus explains that why we could compute the least CPUE value in Winter. Klaoudatos et al. (2010) reported that the mean CPUEs of $P$. acarne and $P$. erythrinus from the Aegean trawl samplings were 4.17 and $17.18 \mathrm{~kg} \mathrm{~h}^{-1}$ in Thermaikos Gulf (Northern Aegean) and 15.32 and $40.58 \mathrm{~kg} \mathrm{~h}^{-1}$ in Argolikos Gulf (Southern Aegean), respectively. It seems that the CPUE values of two Pagellus species in Greek Aegean coasts are the higher than those of Izmir bay however, both species in Southern Aegean are the most abundant than those of Northern Aegean sea according to CPUEs.

In this study, many of the smaller specimens of both fish species caught seem that there is growth over-fishing on the both fish stocks. Two Pagellus populations can not get growth opportunity due to the heavy fishing pressure. However, the exploitation rates ( $\mathrm{E}=0.65$ for $P$. acarne and $\mathrm{E}=0.61$ for $P$. erythrinus) also present the good evidence. The $\mathrm{E}$ was higher than 0.50 for both species. Therefore, the stocks of the two Pagellus species in Izmir bay are being heavily exploited. Ragonese (2009) stated that the growth over-fishing derives from the huge number of recruits and juveniles which are almost exclusively caught by trawlers. Akyol and Ozekinci (2000) calculated that the exploitation rates of both fish from beach-seining in the Aegean sea were 0.84 for $P$. acarne and 0.76 for $P$. erythrinus.

After the banning of beach-seiners in all Turkish territorial waters since 2001, it seems that the exploitation rate is begun to decline. However, some changes in the fishing legislation may be necessary. Carlucci et al. (2009) stated that in such a situation, action to protect recruits becomes quite urgent in order to prevent further stock depletion and this can be achieved through season and/or area closure and/or applying larger mesh size in the codend of the trawl net or nets with different geometry (square vs. diamond).

\section{CONCLUSION}

The results clearly indicated that the two Pagellus species population is over-fished and further studies on population dynamics of these fish should be made for sustaining their stocks and regulating its fishery. For the time being, the fisheries authority should stipulate the $50 \mathrm{~mm}$ diamond mesh size for trawl nets in order to protect the some fish by-catch species which have different body forms and MLS of $15 \mathrm{~cm}$ for $P$. acarne should be placed in TFRC. 


\section{ACKNOWLEDGEMENT}

This study was funded by Turkish Scientific and Technological Research Council (TUBITAK Project No: 106Y029).

\section{REFERENCES}

Akyol, O. and U. Ozekinci, 2000. The effects of beach seine net on some economic fish species in the Aegean Sea. EU Su Urunleri Dergisi, 17: $185-199$.

Akyol, O., 2003. Retained and trash fish catches of beach-seining in the Aegean coast of Turkey. Turk. J. Vet. Anim. Sci., 27: 1111-1117.

Anonymous, 2008. Turkish fishery regulation bulletin (2/1) for marine and inland commercial fisheries in fishing season 2008-2012. T.C. TKBKKGM, R.G. Sayi: 26974, No. 2008/48, Ankara, pp: 112.

Ates, C., M.C. Deval, T. Bok and Z. Tosunoglu, 2010. Selectivity of diamond (PA) and square (PE) mesh codends for commercially important fish species in the Antalya Bay, Eastern Mediterranean. J. Appl. Ichthyol., 26: 465-471.

Aydin, C., A. Tokac, A. Ulas, B. Maktay and T. Sensurat, 2011. Selectivity of $40 \mathrm{~mm}$ square and $50 \mathrm{~mm}$ diamond mesh codends for five species in the eastern Mediterranean demersal trawl fishery. Afr. J. Biotechnol., 10: 5037-5047.

Beverton, R.J.H. and S.J. Holt, 1957. On the dynamics of exploited fish populations. UK Ministry of Agriculture and Fisheries, Fish Invest. (Ser.2), 19, pp: 533.

Carlucci, R., L. Giuseppe, M. Porzia, C. Francesca and M.C. Alessandra et al., 2009. Nursery areas of red mullet (Mullus barbatus), hake (Merluccius merluccius) and deep-water rose shrimp (Parapenaues longirostris) in the Eastern-Central Mediterranean Sea). Estuarine Coastal Shelf Sci., 83: 529-538.

$\mathrm{FAO}, 1999$. Guidelines for the routine collection of capture fishery data. FAO Fish. Tech. Pap., No. 382, Rome.

Froese, R. and D. Pauly, 2011. FishBase. World Wide Web Electronic Publication. Version 06/2011. http://www.fishbase.org/search.php.

Golani, D., B. Ozturk and N. Basusta, 2006. The Fishes of the Eastern Mediterranean. Turkish Marine Research Foundation, Istanbul, Turkey, Pages: 259.
Hureau, J.C. and M.L. Bauchot, 1986. Sparidae. In: Fishes of the North-Eastern Atlantic and the Mediterranean, Whitehead, P.J.P., M.L. Bauchot, J.C. Hureu, J. Nielsen and E. Tortonose (Eds.). Vol. II, UNESCO, Paris, pp: 883-907.

Kinacigil, H.T., A.T. Ilkyaz, G. Metin, A. Ulas, O. Soykan, O. Akyol and R. Gurbet, 2008. Determination of the first maturity length, age and growth of demersal fish stocks in the Aegean Sea. TUBITAK Project No. 103Y132, Final Report, Pages: 325.

Karakulak, F.S. and H. Erk, 2008. Gill net and trammel net selectivity in the northern Aegean Sea Turkey. Sci. Mar., 72: 527-540.

Klaoudatos, D., K. Kapiris, A. Conides, C. Papaconstantinou and S. Glykokokkalos, 2010. Assessment of demersal distribution between two fishing areasin North and Central Greece. Int. Aquat. Res., 2: 143-154.

Metin, G., A.T. Ilkyaz, O. Soykan and H.T. Kinacigil, 2011. Biological characteristics of the common pandora, Pagellus erythrinus (Linnaeus, 1758), in the central Aegean Sea Turk. J. Zool., 35: 307-315.

Moutopoulos, D.K. and K.I. Stergiou, 2002. Length-weight and length-length relationships of fish species from the Aegean Sea (Greece). J. Applied Ichthyol., 18: 200-203.

Ozbilgin, D.Y., Z. Tosunoglu and H. Ozbilgin, 2006. By-catch in a $40 \mathrm{~mm}$ PE demersal trawl codend. Turk. J. Vet. Anim. Sci., 30: 179-185.

Pauly, D., 1980. A selection of simple methods for the assessment of tropical fish stocks. FAO Fisheries Circular, 729, FAO, Rome, pp: 54, http://orton.catie.ac. cr/cgi-bin/wxis.exe/?IsisScript=DINARA.xis\&method $=$ post $\&$ formato $=2 \&$ cantidad $=1 \&$ expresion $=\mathrm{mfn}=$ 000278 .

Petrakis, G., 1998. Catch per unit of effort fluctuations in deep waters in west coast of Greece (Ionian Sea). ICES CM/O:50, Deep Water Fish and Fisheries, Lisbon, Portugal.

Ragonese, S., 2009. Avoidance within a changing assessment paradigm for Mediterranean hake stocks. Mediterranean Mar. Sci., 10: 125-130.

Santos, M.M., C.C. Monteiro and K. Erzini, 1995. Aspects of the biology and gillnet selectivity of the axillary seabream (Pagellus-acarne, Risso) and common pandora (Pagellus-erythrinus, Linnaeus) from the Algarve (South Portugal). Fish. Res., 23: 223-236.

Sparre, P. and S.C. Venema, 1992. Introduction to tropical fish stock assessment Part 1: Manual. FAO Fisheries Technical Paper 306/1, Rev. 1, pages: 376. 
Spedicato, M.T., S. Greco, K. Sophronidis, G. Lembo, D. Giordano and A. Argyri, 2002. Geographical distribution, abundance and some population characteristics of the species of the genus Pagellus (Osteichthyes: Perciformes) in different areas of the Mediterranean. Sci. Mar., 66: 65-82.

Tosunoglu, Z., 2007. Trawl codend design (44 mm diamond PE mesh) and the effect on selectivity for Pagellus erythrinus and Pagellus acarne, two species with different morphometrics. J. Applied Ichthyol., 23: 578-582.
Tosunoglu, Z., O. Akyol, G. Metin, A. Tokac and S. Unsal, 1997. The study on the population characteristics of three sparid species in the Gulbahce Bay. EU Su Urunleri Dergisi, 14: 127-143.

Tosunoglu, Z., Y.D. Ozbilgin and H. Ozbilgin, 2003. Body shape and trawl cod-end selectivity for nine commercial fish species. J. Mar. Biol. Assoc. UK. 83: 1309-1313.

Tuik, 2010. Fishery Statistics 2009. Turkish Statistical Institute, Ankara, pages: 59. 